\title{
Genetic influence on East African running success
}

\author{
Robert A Scott', Colin Moran', Richard H Wilson', \\ Will H Goodwin ${ }^{2}$ and Yannis P Pitsiladis ${ }^{1, *}$ \\ ${ }^{1}$ International Centre for East African Running Science (ICEARS), Institute of Biomedical \\ \& Life Sciences, University of Glasgow, Glasgow G12 8QQ, UK \\ ${ }^{2}$ Department of Forensic and Investigative Science, University of Central Lancashire, \\ Preston PR $12 \mathrm{HE}$, UK \\ *Corresponding author: Y.Pitsiladis@bio.gla.ac.uk
}

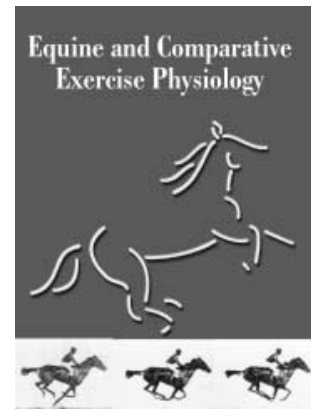

\begin{abstract}
East African athletes now dominate international distance running events from the $800 \mathrm{~m}$ to the marathon. Explanations for their phenomenal success have included optimal environmental conditions for developing distance running performance, psychological advantage and advantageous physiological characteristics. It is well established that genetics plays a role in determining inter-individual differences in exercise performance and adaptation to training stimuli. It is not known, however, to what extent inter-population differences (i.e. between 'races' and/ or ethnic groups) in exercise performance can be attributed to genetics. There have been considerations that 'black' athletes are genetically adapted towards performance, given the concurrent success of athletes of West African ancestry in sprint events. However, the current notion of 'race' is not universally accepted, and genetic differences within and between populations are not clearly delineated by geographical or ethnic categorizations. Recent findings from mitochondrial DNA show that the populations from which Ethiopian athletes are drawn have not been isolated populations and are not genetically distinct from other Ethiopians. Y-chromosome analysis of the same population shows concurrent results, although some differences are present between athletes and the general Ethiopian population, suggesting an influence of the Y chromosome on athlete status in Ethiopia. It is concluded that there may be a role for genetics in the success of East African athletes; however, any genetic component to their success is unlikely to be limited to East Africans and is more likely to be found in other populations. At present it is unjustified to implicate a role for genetics in the success of East African runners when no genes have been identified as being important to their performance.
\end{abstract}

Keywords: Kenya; Ethiopia; athletics; genetics; mitochondrial DNA; Y chromosome

\section{Introduction}

Why some ethnic and/or 'racial' groups consistently outperform others in the sporting arena has been a topic of great research interest, with the 'nature' versus 'nurture' debate at the fore. For example, the USA has dominated basketball in international competition in the same way as the Chinese have enjoyed particular success in table tennis. Social scientists have attributed such sporting dominance to differences in participation rates, coaching and training ${ }^{1}$. However, there are other examples where explanations of coaching and training cannot be applied so readily, such as in athletic track events. The current world record-holders for the $100 \mathrm{~m}$ to the marathon for males are all of 'black' African ancestry (Table 1). This has led to the presumption that 'black' athletes are genetically endowed 'natural' athletes ${ }^{2}$. The particular example discussed here is that of East African athletes, who now dominate in track events upwards of $800 \mathrm{~m}$ as well as in international cross-country and road racing events. In the 2003 World International Association of Athletics Federations' Championships in Paris for example, athletes from Ethiopia and Kenya won nine of the 12 available medals for the $5000 \mathrm{~m}$ and $10000 \mathrm{~m}$.

A number of explanations have been proposed to account for the success of East African athletes. These have included optimal environmental conditions for developing distance running performance, psychological advantage and advantageous physiological characteristics; the evidence for each of these factors is discussed in more detail elsewhere in this issue ${ }^{3}$. The explanation frequently offered, but substantiated primarily by compelling statistics of differential ethnic and/or 'racial' athletic success and non-scientific evidence, is that East African athletes possess favourable 
Table 1 Men's world running records

\begin{tabular}{|c|c|c|c|}
\hline Event & Athlete & Time & Ancestry \\
\hline $100 \mathrm{~m}$ & Tim Montgomery (USA) & $9.78 \mathrm{~s}$ & West Africa \\
\hline $110 \mathrm{~m}$ hurdles & Colin Jackson (Great Britain) & $12.91 \mathrm{~s}$ & West Africa \\
\hline $200 \mathrm{~m}$ & Michael Johnson (USA) & $19.32 \mathrm{~s}$ & West Africa \\
\hline $400 \mathrm{~m}$ & Michael Johnson (USA) & $43.18 \mathrm{~s}$ & West Africa \\
\hline $400 \mathrm{~m}$ hurdles & Kevin Young (USA) & $46.78 \mathrm{~s}$ & West Africa \\
\hline $800 \mathrm{~m}$ & Wilson Kipketer (Kenya) & $1 \mathrm{~min} 41.11 \mathrm{~s}$ & East Africa \\
\hline $1000 \mathrm{~m}$ & Noah Ngeny (Kenya) & $2 \min 11.96 \mathrm{~s}$ & East Africa \\
\hline $1500 \mathrm{~m}$ & Hicham El Guerrouj (Morocco) & $3 \mathrm{~min} 26.00 \mathrm{~s}$ & North Africa \\
\hline Mile & Hicham El Guerrouj (Morocco) & $3 \min 43.12 \mathrm{~s}$ & North Africa \\
\hline $3000 \mathrm{~m}$ & Daniel Komen (Kenya) & $7 \mathrm{~min} 20.67 \mathrm{~s}$ & East Africa \\
\hline $5000 \mathrm{~m}$ & Kenenisa Bekele (Ethiopia) & $12 \min 37.35 \mathrm{~s}$ & East Africa \\
\hline $10000 \mathrm{~m}$ & Kenenisa Bekele (Ethiopia) & $26 \mathrm{~min} 20.31 \mathrm{~s}$ & East Africa \\
\hline Marathon & Paul Tergat (Kenya) & $2 \mathrm{~h} 4 \min 55 \mathrm{~s}$ & East Africa \\
\hline
\end{tabular}

genetics for superior middle- and long-distance running ${ }^{4-7}$. East African athletes are not evenly distributed throughout East Africa, but are concentrated among particular ethnically and geographically defined populations. In Kenya, the Nandi people are recognized as producing the most successful runners ${ }^{8}$, and in Ethiopia, the Oromo people, particularly those from Arsi are particularly prevalent among elite athletes 9 . Anecdotal explanations for this have included the possibility that the Nandi have been genetically adapted towards endurance performance as a result of selection for those with greater prowess in hunting or gathering. As shall be discussed, it is certainly conceivable that genetics is influential in the determination of athletic success; however, there are ways in which genetics may be important in the success of East African distance runners and ways in which it may not.

The present review attempts to discuss the theoretical basis of a 'racial' and/or ethnic genetic predisposition for superior running performance in East Africans by reviewing the few available studies on the genetics of elite human physical performance and data from selected anthropological/evolutionary studies, as well as recent genetic data of elite East African runners.

\section{Genetics of elite human physical performance}

In an attempt to identify the extent to which adaptive variation is attributable to an uncharacterized genetic effect, heritability studies using twin models were able to show that physiological characteristics such as maximal oxygen uptake $\left(\mathrm{V}_{2} \mathrm{O}_{2 \max }\right)$ had a strong genetic component ${ }^{10,11}$. However, such studies often provide equivocal results, and are confounded by a number of factors (for a review, see Klissouras ${ }^{12}$ ). A number of elaborate genetic studies of human physical performance have emerged more recently, aided substantially by technological advances in the field of molecular genetics. A yearly publication summarizing the literature on the genetics of physical performance has now identified in excess of 100 genetic variants that can effect muscular, morphological and cardiorespiratory factors (albeit mainly in non-elite athletes) ${ }^{13-15}$. Such genetic variants may account for some of the differences in physical performance between elite and non-elite athletic populations. However, at present, the extent to which elite athlete status is associated with particular performance genes is unknown, owing to a number of contrasting results $^{16-20}$. Factors such as inevitably low subject numbers for truly elite athletes may confound associations, and may partially explain the discrepancies in the findings.

Perhaps the most studied of the putative 'performance' genes is the angiotensin-converting enzyme $(A C E)$ gene, which contains an intronic insertion polymorphism. The insertion (I) allele is associated with lower levels of circulating ACE than the deletion (D) allele $^{21}$. The $A C E$ I allele has been associated with endurance performance ${ }^{22}$, and has been shown to be more prevalent in elite endurance athletes compared to a normal population ${ }^{17}$ or athletes specializing in shorter distances $^{23}$, although these results have not always been supported ${ }^{20}$ (see Payne and Montgomery ${ }^{24}$ for a recent review). Another promising 'performance' gene is the $\alpha$-actinin-3 gene that codes for a protein restricted largely to fast glycolytic skeletal muscle fibres (see MacArthur and North ${ }^{25}$ for a recent review). A variant of this gene, which inactivates the protein product, has been associated with athletic performance. This variant is less frequent in Olympic-standard sprint athletes than in endurance athletes or matched non-athlete controls $^{26}$. Polymorphisms in the muscle-specific creatine kinase (CKMM) gene locus were not found to be associated with elite endurance athlete status ${ }^{27}$, despite having been associated with adaptation of $\dot{\mathrm{V}} \mathrm{O}_{2 \max }$ to a standardized training programme ${ }^{28}$.

Despite the lack of conclusive evidence for an influence of genetics on the determination of elite athlete status, there is a great deal of support for the idea that genetics does influence some of the inter-individual differences in health-related fitness phenotypes $^{13-15}$. However, although genetics may account 
for some of the inter-individual differences in physical performance, the extent to which it may influence the inter-population differences (i.e. between 'races' and/ or ethnic groups) in performance is yet to be determined.

\section{The genetics of 'race' and East African running dominance}

The success of East African athletes in distance running and of athletes of West African ancestry in the shorter distances has perpetuated the idea that 'black' athletes are genetically adapted for athletic performance ${ }^{2}$. This notion is based on a preconception that each 'race' constitutes a genetically homogeneous group, with 'race' being defined simply by skin colour. This notion is contrary to the assertion that there is more genetic variation within Africa than between the average African and Eurasian ${ }^{29}$. It is estimated that most human genetic variation is shared by all humans and that a marginal proportion (approximately 10\%) is specific to groups as defined by geography or skin colour (see Bouchard $^{30}$ ). Alleles found in one population are usually common to all human populations, particularly when they occur at a frequency of over $20 \%$ in a population ${ }^{31}$. Consequently, any differences in physiology, biochemistry and/or anatomy between groups defined solely by skin colour (e.g. 'black' vs. 'white') are inapplicable to East African runners, even if the differences found are indeed genetically determined. This argument would also apply to any comparison between Kenyan and Ethiopian athletes despite these populations being closer geographically. Even within countries like Kenya and Ethiopia, any group comparisons based only on skin colour would be subject to the same methodological constraints due to the greater genetic diversity inherent in African populations.

A 'race' is generally considered to have shared common ancestry. However, based on recent estimates, all modern humans shared a common ancestor in the last 200000 years $^{32}$. Populations outwith Africa are considered to have arisen from movements out of Africa and are therefore likely to be constructed from selected subsets of African genetic variation. This has prompted some advocacy that 'race' should be abandoned as a tool for assessing the prevalence of disease genotypes in certain populations, and that 'race' is not an acceptable surrogate for genetics in assessing these risks $^{33}$. Others, however, argue that there is a role for 'race', and that the potential benefits to be gained in terms of diagnosis and research of disease outweigh the potential social costs of linking 'race' or ethnicity with genetics ${ }^{32}$. Arguments for the inclusion of 'race' in biomedical research often focus on the use of the term to identify single gene disorders and their medical outcome, and it is acknowledged that the genetic basis of complex phenotypes, such as athletic performance, is poorly understood and far more difficult to study. This debate focuses on the question of whether geographically or culturally defined populations can be differentiated by their genetics. It is argued that humans do indeed form genetic clusters of African, Asian, Caucasian and Pacific Islanders, but it is also acknowledged that there are a number of exceptions including some East African populations such as Ethiopia. Ethiopia, which has had a significant admixture from Middle Eastern groups, has been found to cluster more closely with Caucasian groups than with other African groups in certain studies ${ }^{34}$.

Despite the ongoing debate and confusion surrounding the use of concepts such as 'race', ethnicity and genetics, one should be wary of ascribing genetic effects as being 'race'-specific ${ }^{35}$. At the individual level, 'race' is not an acceptable proxy for genetics (i.e. the genotype of an individual can only be determined by genetic analysis of that individual).

\section{Matrilineal genetics and the dominance of East Africans in world distance running}

A study of Ethiopian runners was recently undertaken in an attempt to address some of the issues raised in the previous section. This study involved the collection of demographic information and genetic material from 76 elite Ethiopian runners (including Olympic and World Champions) and an Ethiopian control population ${ }^{9}$. The demographic results revealed that elite Ethiopian distance runners were of a distinct ethnic and environmental background, relative to the general Ethiopian population'. These demographic results highlight the importance of environment in the determination of endurance athletic success without excluding any genetic effect. A possible genetic effect in this cohort was studied subsequently by comparing the mitochondrial DNA (mtDNA) haplogroup distribution of the elite Ethiopian athletes relative to the general Ethiopian population ${ }^{36}$. Findings of a maternal effect in the inheritance of $\mathrm{VO}_{2 \max }{ }^{11}$ hinted at a possible influence of mtDNA in the determination of aerobic capacity. In addition to polymorphisms in the nuclear genome, some studies have suggested that polymorphisms in mtDNA may account for some of the inter-individual differences in endurance performance and response to endurance training ${ }^{37,38}$ (for a review, see Rupert ${ }^{39}$ ). Intriguing evidence of adaptive selection of mtDNA types to colder climates $^{40}$, through an increased emphasis on thermogenic activity of mitochondria, raises the question of whether those from warm environments have maintained more efficient mitochondria, perhaps contributing to the superior running economy of East Africans. mtDNA is a circular, double-stranded DNA molecule 
of $16569 \mathrm{bp}$ which encodes 13 subunits of a number of enzyme complexes of oxidative phosphorylation, as well as components of the mitochondrial protein synthesis system $^{41}$. mtDNA is passed intact from mother to offspring and changes only with the occurrence of new mutations, which allows phylogenetic trees of human evolution to be constructed. A simplified mtDNA tree is shown in Fig. 1. At the root of this tree is 'Mitochondrial Eve' (mtEve), the common maternal ancestor of all modern humans who lived in East Africa around 170000 years ago $^{32}$. Each of the descending branches of the tree is known as a haplogroup and is defined by the presence or absence of haplogroup-specific polymorphisms. The earliest lineages are known as L1 types, which are almost exclusive to Africa, and are thought to have arisen in East Africa. The mtDNA haplogroup distribution found in a population can give insight into their ancestry ${ }^{44}$. In Ethiopia, there are a wide variety of mtDNA types belonging, in almost equal proportions, to all of the major African types (i.e. L1, L2 and L3) ${ }^{45}$. These types are divergent and coalesce over 100000 years ago in the time of mtEve. Given that athletic success in East Africa is concentrated in particular subsets of the East African population', it was of interest to establish if this population was genetically distinct as defined by mtDNA type.

Given that mtDNA haplogroups are defined by the presence of polymorphisms (as discussed later, some of which may have functional significance), combined with a lack of recombination, if mtDNA polymorphisms were important in the success of Ethiopian distance runners, selection for the mutants beneficial to exercise performance would lead to an increased frequency of the haplogroups that carry the polymorphism amongst elite athletes. Also, as some of the mtDNA haplogroups

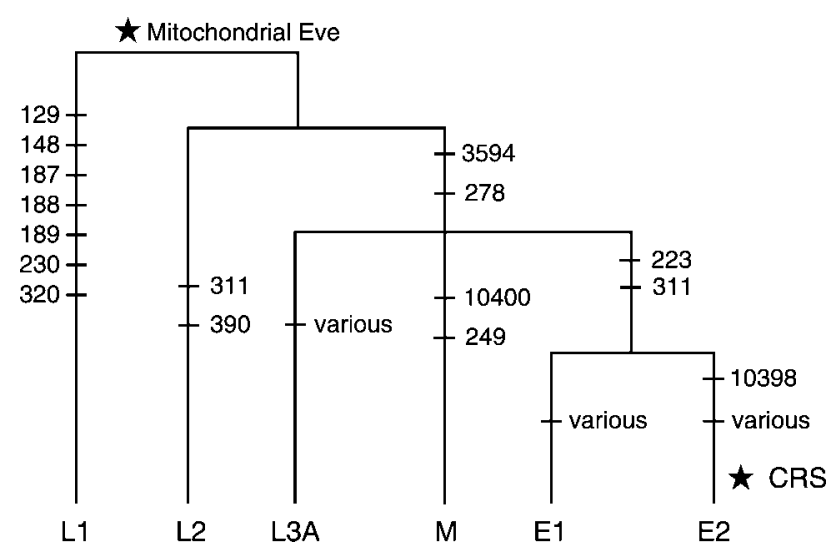

FIG. 1 Human mitochondrial tree. Approximate positions of polymorphisms relative to the Cambridge Reference Sequence (CRS) are shown (hypervariable segment I polymorphisms are shown minus 16000). Haplogroup topology is modelled upon more detailed human phylogenies ${ }^{42,43}$. Approximate positions of the ancestral mitochondrial DNA sequence 'Mitochondrial Eve' and the CRS are also shown. found commonly in Ethiopia are less frequent outwith East Africa, if any of these haplogroups contain beneficial mutants, this would raise the question of whether this may partially account for the success of East African athletes in international distance running. The haplogroup distribution in the control group (109 subjects intended to be representative of the general Ethiopian population) was compared with that in 76 elite Ethiopian endurance athletes competing at distances from $5000 \mathrm{~m}$ to marathon ${ }^{36}$. The haplogroup distribution of the control group was similar to data previously published ${ }^{46-48}$, with a divergent range of mtDNA haplogroups and a high proportion of $\mathrm{L}$ and M haplogroups. Rather than the athletes being restricted to one branch of the tree, they too were widespread throughout, with no statistical difference from the control group. These findings do not support the hypothesis of a role for mtDNA polymorphisms in the determination of East African running success. Furthermore, the diversity of mtDNA found in the athlete group is in contrast to the notion that they are a genetically distinct group, as defined by mtDNA. Some of the athletes share a more recent common mtDNA ancestor with many Europeans than they do with other elite Ethiopian athletes. In addition, no difference in mtDNA haplogroup distribution was found between geographically or ethnically defined groups. When the mtDNA distribution of subjects from the Arsi region of Ethiopia, which produces a disproportionate number of elite athletes, was compared with that of other regions, it was found that the Arsi population had an mtDNA distribution equally as diverse as other regions. This finding does not support the hypothesis that such populations have remained genetically isolated for long periods of time.

The results of the Ethiopian study ${ }^{36}$ suggest that mtDNA polymorphisms are not a major determinant of the success of East African athletes. As the haplogroups are defined by the polymorphisms they contain, any haplogroup containing a functional variant would be likely to change in frequency in the elite athletes relative to controls as a result of selection. As this was not found to be the case, it is unlikely that they are influential in the success of Ethiopian distance runners.

\section{Patrilineal genetics and the dominance of East Africans in world distance running}

The Y chromosome, like mtDNA, is interesting because it is inherited solely through a single sex (i.e. the male). Although often ignored in genetic association studies, the $\mathrm{Y}$ chromosome is a potentially interesting candidate to study. While poor in genes and non-essential for survival (given the presence of $\mathrm{XX}$ females), it could in principle carry gene variants 
that might influence physical performance specifically in males, which may explain why the dominance of East African runners is primarily a male phenomenon (i.e. more than a sociological phenomenon linked to participation rates). The haploid nature of the chromosome means that it does not recombine, and thus haplotypes pass undisturbed from one generation to the next, with changes arising only due to new mutations. The availability of a unique and highly resolved phylogeny ${ }^{49}$ based on binary markers, such as single nucleotide polymorphisms, allows haplogroups to be defined. The frequencies of particular haplogroups can then be compared between subject and control groups. Positive associations have previously been reported between specific haplogroups, a number of phenotypes (reviewed by Jobling and Tyler-Smith ${ }^{50}$ ) and ethnic origin ${ }^{46,47,51}$. It is possible that there is something unique about the distribution of East African Y-chromosome haplogroups that is influencing their endurance performance.

Recently, Moran et al. ${ }^{52}$ studied the association between the $\mathrm{Y}$ chromosome and endurance athlete status in Ethiopians in an attempt to examine whether elite Ethiopian runners are indeed a genetically distinct group as some may infer from the published Ethiopian demographic data ${ }^{9}$. To address potential population stratification effects, two control populations were used: a general Ethiopian control and a second control comprised of individuals from the Arsi region (known to be the source of a disproportionate number of athletes). The athlete cohort was the same as in the previous studies ${ }^{36}$, although confined to males in this instance. The distribution of the Y-chromosome haplogroups of the Ethiopian subjects is shown in Fig. 2. There were significant differences between the general Ethiopian control and the $5-10 \mathrm{~km}$ and combined endurance runners $(5-10 \mathrm{~km}$ and marathon runners), and between the Arsi control and the 5-10 km runners, the marathon runners and the endurance athletes as a whole. On deeper investigation, these associations appeared to have been produced by four haplogroups: $\mathrm{E}^{*}, \mathrm{E}^{*}, \mathrm{E} 3 \mathrm{~b} 1$ and $\mathrm{K}^{*}(\mathrm{xP})$. Haplogroups $\mathrm{E}^{*}, \mathrm{E}^{*}$ and $\mathrm{K}^{*}(\mathrm{xP})$ were positively associated with elite performance in one or both endurance events, whilst haplogroup E3b1 was negatively associated with endurance performance. The finding that Y-chromosome haplogroups are associated with elite athlete status in Ethiopians suggests that either an element of the Y-chromosome genetics is influencing athletic performance or that the Y-chromosome haplogroup distributions were affected by population stratification. However, the range of haplogroups in the athlete groups was similar to that in the two control groups, and haplogroups in both control and athlete groups

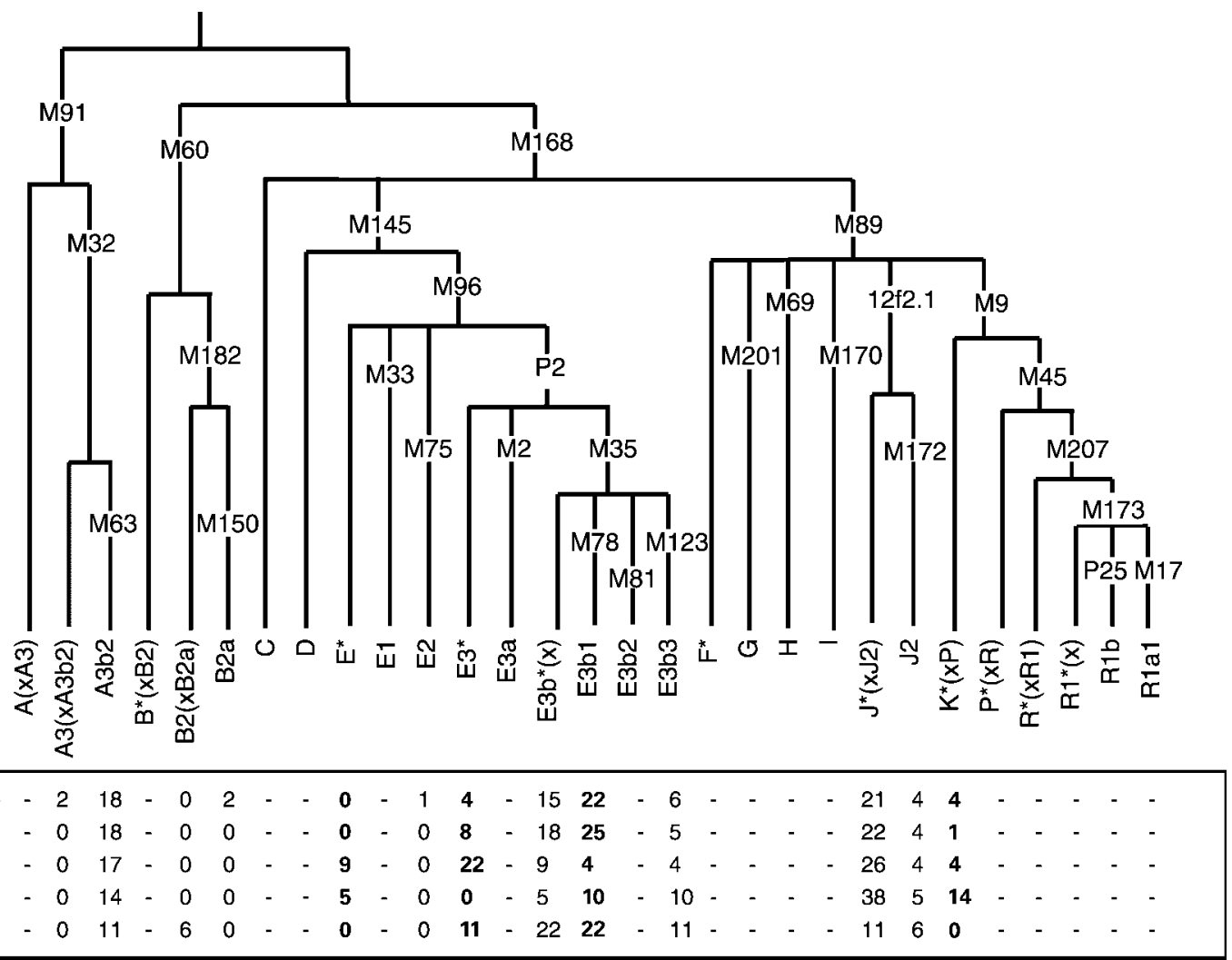

FIG. 2 Phylogenetic tree of the Y-chromosome haplotypes and their percentage frequencies. All mutations shown were examined in the present study. $n$ for each group is given in parentheses. Abbreviations used in figure: $E 3 b(x)$ represents $E 3 b^{*}(x E 3 b 1, E 3 b 2, E 3 b 3)$ and $\mathrm{R} 1^{*}(\mathrm{x})$ represents $\mathrm{R} 1^{*}(\mathrm{xR} 1 \mathrm{a} 1, \mathrm{R} 1 \mathrm{~b})$. Data from Moran et al. ${ }^{52}$. 
were similar to those previously identified as being present in Ethiopian samples ${ }^{47,51}$. Nor was any association found between the Y-chromosome haplogroups of the subjects and their place of birth or language family. The observed associations could not, therefore, be readily explained by regional or cultural affiliation, and were less likely to be a result of simple population stratification. If there was something special about the genetics of the Arsi population that was predisposing them to endurance athletics, it might have been expected that the two control groups would be significantly different, and that the endurance athletes would be statistically different from the general control but very similar to the Arsi control. However, no difference was found between the control groups and more differences were observed between the athletes and the Arsi control than between the athletes and the general control. This raised the question of whether or not the Arsi control population was representative of the Arsi populations from which the athletes originated. Despite this, there were still differences between the athlete groups and the general Ethiopian control, suggesting that the athletes were a distinct group. With population stratification ruled out, something about the Y-chromosome biology of the athletes must have been influencing their athletic abilities directly.

Although once thought to be devoid of genes, merely full of repetitive and parasitic sequences, geneticists' views on the Y chromosome have changed. The male-specific region (MSY) is now estimated to contain 156 genes $^{53}$, some of which are expressed throughout the body. Despite this, there are as yet no clear candidates for genes directly affecting athletic ability. The conclusions from the Ethiopian study ${ }^{52}$ are that elite Ethiopian endurance runners are not spread throughout the Y-chromosome haplogroup tree in the same proportions as the general population, with significant differences in four of the individual Y-chromosome haplogroups between elite athletes and controls. Although it remains possible that these associations were a result of population stratification, it would be of interest to test for the same haplogroup associations in other East African athletic populations, such as the Kenyans. If the same haplogroups were under/overrepresented, this would provide strong evidence for a biological effect of the Y chromosome on elite athlete status.

The finding that populations such as those in the Arsi highlands have not arisen from a limited genetic isolate over thousands of years does not rule out an influence of genetics on their disproportionate success in distance running. In fact, recent reports on genetically modulated responses to altitude may offer some insight into ways in which genetics may influence their success. Evidence of different strategies for coping with hypobaric hypoxia ${ }^{54}$ used by geographi- cally isolated indigenous populations may suggest that the unique adaptations of East Africans have some influence on their endurance success. Genes involved in the hypoxic response have been found to be polymorphic ${ }^{55}$, with some polymorphisms varying significantly in frequency between high- and low-altitude populations. The possibility exists, therefore, that variants having been selected for benefits in oxygen transport have the potential to concurrently influence the endurance phenotype. Although unlikely to be a genetic influence isolated to East Africans, it is entirely possible that subtle changes in the frequency of particular candidate genes for human performance may have an influence on the disproportionate success of East Africans. The aforementioned $A C E$ gene is a particular example of how there may be a genetic effect acting on the success of East Africans which is not entirely specific to them. The I allele of the $A C E$ gene has been implicated as important in high-altitude tolerance ${ }^{56}$, shown by an increased frequency of climbers with at least one I allele being able to tolerate high altitude. It is plausible, therefore, in high-altitude populations such as those found in East Africa, that there has been a selective advantage for those carrying the I allele. As discussed earlier, the I allele has also been associated with endurance performance, which raises the possibility that the highland East Africans may have been adapted towards endurance performance indirectly. However, the lack of conclusive evidence on the role of the $A C E$ I allele in endurance performance further attests to the belief that a single gene effect is unlikely to be the final arbiter between success and failure in athletic performance, particularly not in differentiating between populations.

\section{Conclusions}

It is concluded that, at present, there is no evidence that genetics plays a role in determining East African running success, and that any genetic effect is more likely to be as a result of an increased frequency of a particular candidate gene, not unique to East Africa, but conferring advantage in any population. Any allele that is having a major influence on the success of East Africans is likely to be present in most other groups, as it is estimated that any allele present in a population at a frequency of over $20 \%$ is almost certainly present in other populations at reasonable frequencies $^{31}$. Findings that South African runners exhibit advantageous physiological characteristics, even if genetically determined, are unable to be extrapolated to East African athletes given the current understanding of 'race' and genetics. Rather than unique genetics, what may be unique about East Africans is their combination of social and cultural factors, such as strong traditions of distance running, 
as well as optimal environmental conditions such as running long distances to school each day. It may also be the case that those with an advantageous combination of potential performance genes, conferring advantage in endurance performance, recognize their talent through using it regularly. It can be concluded that it is unjustified at present to identify the phenomenon of East African running success as a genetically mediated one, and that to justify doing so, one must identify the genes which are important. The unsubstantiated concept that East Africans are genetically adapted towards distance running leads to the perception amongst opponents that they are at a disadvantage, which will only serve to perpetuate the myth through stereotype threat ${ }^{57}$.

\section{Acknowledgements}

The authors acknowledge the invaluable assistance of Athletics Kenya, the Ethiopian Olympic Committee, the Ethiopian Athletics Federation and Kotebe College. The Royal Society, The Carnegie Trust for the Universities of Scotland and The Wellcome Trust are gratefully acknowledged for part-funding this research.

\section{References}

1 Phillips JC (1976). Toward an explanation of racial variation in top-level sports participation. International Review of Sports and Sociology 11(3): 39-55.

2 Entine J (2001). In: Entine J, Salles G and Kearney JT (eds), Why Black Athletes Dominate Sports and Why We are Afraid to Talk about it. New York: Public Affairs.

3 Pitsiladis YP, Onywera VO, Geogiades E, O'Connell W and Boit MK (2004). The dominance of Kenyans in distance running. Equine and Comparative Exercise Physiology 1(4): 285-291.

4 Larsen HB (2003). Kenyan dominance in distance running. Comparative Biochemistry and Physiology. Part A, Molecular \& Integrative Physiology 136(1): 161-170.

5 Entine J (2001). Race and sport. The race to the swift - if the swift have the right ancestry. Peak Performance Special Issue. Race and Genetics 158: 1-6.

6 Saltin B, Kim CK, Terrados N, Larsen H, Svedenhag J and Rolf CJ (1995). Morphology, enzyme activities and buffer capacity in leg muscles of Kenyan and Scandinavian runners. Scandinavian Journal of Medicine \& Science in Sports 5(4): $222-230$.

7 Saltin B (1996). Exercise and the environment: focus on altitude. Research Quarterly for Exercise and Sport 67: (Suppl. 3) S1-S10.

8 Bale J and Sang J (1996). Kenyan Running: Movement Culture, Geography, and Global Change. London: Frank Cass.

9 Scott RA, Georgiades E, Wilson RH, Goodwin WH, Wolde B and Pitsiladis YP (2003). Demographic characteristics of elite Ethiopian endurance runners. Medicine and Science in Sports and Exercise 35(10): 1727-1732.

10 Fagard R, Bielen E and Amery A (1991). Heritability of aerobic power and anaerobic energy generation during exercise. Journal of Applied Physiology 70(1): 357-362.

11 Lesage R, Simoneau JA, Jobin J, Leblanc J and Bouchard C (1985). Familial resemblance in maximal heart rate, blood lactate and aerobic power. Human Heredity 35(3): $182-189$.

12 Klissouras V (1997). Heritability of adaptive variation: an old problem revisited. Journal of Sports Medicine and Physical Fitness 37(1): 1-6.

13 Perusse L, Rankinen T, Rauramaa R, Rivera MA, Wolfarth B and Bouchard C (2003). The human gene map for performance and health-related fitness phenotypes: the 2002 update. Medicine and Science in Sports and Exercise 35(8): 1248-1264.

14 Rankinen T, Perusse L, Rauramaa R, Rivera MA, Wolfarth B and Bouchard C (2001). The human gene map for performance and health-related fitness phenotypes. Medicine and Science in Sports and Exercise 33(6): 855-867.

15 Rankinen T, Perusse L, Rauramaa R, Rivera MA, Wolfarth B and Bouchard C (2002). The human gene map for performance and health-related fitness phenotypes: the 2001 update. Medicine and Science in Sports and Exercise 34(8): 1219-1233.

16 Taylor RR, Mamotte CD, Fallon $\mathrm{K}$ and van Bockxmeer FM (1999). Elite athletes and the gene for angiotensin-converting enzyme. Journal of Applied Physiology 87(3): $1035-1037$.

17 Gayagay G, Yu B, Hambly B, Boston T, Hahn A, Celermajer DS et al. (1998). Elite endurance athletes and the ACE I allele - the role of genes in athletic performance. Human Genetics 103(1): 48-50.

18 Woods D, Hickman M, Jamshidi Y, Brull D, Vassiliou V, Jones A et al. (2001). Elite swimmers and the D allele of the ACE I/D polymorphism. Human Genetics 108(3): 230-232.

19 Nazarov IB, Woods DR, Montgomery HE, Shneider OV, Kazakov VI, Tomilin NV et al. (2001). The angiotensin converting enzyme I/D polymorphism in Russian athletes. European Journal of Human Genetics 9(10): 797-801.

20 Rankinen T, Wolfarth B, Simoneau JA, Maier-Lenz D, Rauramaa R, Rivera MA et al. (2000). No association between the angiotensin-converting enzyme ID polymorphism and elite endurance athlete status. Journal of Applied Physiology 88(5): 1571 - 1575 .

21 Rigat B, Hubert C, Alhenc-Gelas F, Cambien F, Corvol P and Soubrier F (1990). An insertion/deletion polymorphism in the angiotensin I-converting enzyme gene accounting for half the variance of serum enzyme levels. Journal of Clinical Investigation 86(4): 1343-1346.

22 Woods DR, Brull D and Montgomery HE (2000). Endurance and the ACE I/D polymorphism. Science Progress 83: 317-336.

23 Myerson S, Hemingway H, Budget R, Martin J, Humphries S and Montgomery H (1999). Human angiotensin I-converting enzyme gene and endurance performance. Journal of Applied Physiology 87(4): 1313-1316.

24 Payne $\mathrm{J}$ and Montgomery $\mathrm{H}$ (2004). Angiotensin-converting enzyme and human physical performance. Equine and Comparative Exercise Physiology 1(4): 255-260.

25 MacArthur DG and North KN (2004). A gene for speed? The evolution and function of alpha-actinin-3. Bioessays 26(7): 786-795.

26 Yang N, MacArthur DG, Gulbin JP, Hahn AG, Beggs AH, Easteal S et al. (2003). ACTN3 genotype is associated with human elite athletic performance. American Journal of Human Genetics 73(3): 627-631.

27 Rivera MA, Dionne FT, Wolfarth B, Chagnon M, Simoneau JA, Perusse L et al. (1997). Muscle-specific creatine kinase gene polymorphisms in elite endurance athletes and sedentary controls. Medicine and Science in Sports and Exercise 29(11): $1444-1447$.

28 Rivera MA, Dionne FT, Simoneau JA, Perusse L, Chagnon M, Chagnon Y et al. (1997). Muscle-specific creatine kinase gene polymorphism and $\mathrm{VO}_{2 \max }$ in the HERITAGE Family 
Study. Medicine and Science in Sports and Exercise 29(10): $1311-1317$.

29 Yu N, Chen FC, Ota S, Jorde LB, Pamilo P, Patthy L et al. (2002). Larger genetic differences within Africans than between Africans and Eurasians. Genetics 161(1): 269-274.

30 Bouchard C (1988). Genetic basis of racial differences. Canadian Journal of Sport Sciences 13(2): 104-108.

31 Burchard EG, Ziv E, Coyle N, Gomez SL, Tang H, Karter AJ et al. (2003). The importance of race and ethnic background in biomedical research and clinical practice. New England Journal of Medicine 348(12): 1170-1175.

32 Ingman M, Kaessmann H, Paabo S and Gyllensten U (2000). Mitochondrial genome variation and the origin of modern humans. Nature 408(6813): 708-713.

33 Cooper RS, Kaufman JS and Ward R (2003). Race and genomics. New England Journal of Medicine 348(12): 1166-1170.

34 Wilson JF, Weale ME, Smith AC, Gratrix F, Fletcher B, Thomas MG et al. (2001). Population genetic structure of variable drug response. Nature Genetics 29(3): 265-269.

35 Pearce N, Foliaki S, Sporle A and Cunningham C (2004). Genetics, race, ethnicity, and health. British Medical Journal 328(7447): 1070-1072.

36 Scott RA, Wilson RH, Goodwin WH, Moran CN, Georgiades E, Wolde B et al. (2004). Mitochondrial DNA lineages of elite Ethiopian athletes. Comparative Biochemistry and Physiology. Part A, Molecular \& Integrative Physiology (submitted for publication).

37 Dionne FT, Turcotte L, Thibault MC, Boulay MR, Skinner JS and Bouchard C (1993). Mitochondrial DNA sequence polymorphism, $\mathrm{VO}_{2 \max }$, and response to endurance training. Medicine and Science in Sports and Exercise 25(7): 766-774.

38 Murakami H, Ota A, Simojo H, Okada M, Ajisaka R and Kuno $\mathrm{S}$ (2002). Polymorphisms in control region of mtDNA relates to individual differences in endurance capacity or trainability. Japanese Journal of Physiology 52(3): 247-256.

39 Rupert JL (2003). The search for genotypes that underlie human performance phenotypes. Comparative Biochemis try and Physiology. Part A, Molecular \& Integrative Physiology 136(1): 191-203.

40 Ruiz-Pesini E, Mishmar D, Brandon M, Procaccio V and Wallace DC (2004). Effects of purifying and adaptive selection on regional variation in human mtDNA. Science 303(5655): 223-236.

41 Anderson S, Bankier AT, Barrell BG, de Bruijn MH, Coulson AR, Drouin J et al. (1981). Sequence and organization of the human mitochondrial genome. Nature 290(5806): $457-465$.

42 Maca-Meyer N, Gonzalez AM, Larruga JM, Flores C and Cabrera VM (2001). Major genomic mitochondrial lineages delineate early human expansions. BMC Genetics 2(1): 13.

43 Macaulay V, Richards M, Hickey E, Vega E, Cruciani F, Guida $\mathrm{V}$ et al. (1999). The emerging tree of West Eurasian mtDNAs: a synthesis of control-region sequences and
RFLPs. American Journal of Human Genetics 64(1): 232-249.

44 Richards M, Macaulay V, Hickey E, Vega E, Sykes B, Guida V et al. (2000). Tracing European founder lineages in the Near Eastern mtDNA pool. American Journal of Human Genetics 67(5): 1251-1276.

45 Salas A, Richards M, De la Fe T, Lareu MV, Sobrino B, Sanchez-Diz P et al. (2002). The making of the African mtDNA landscape. American Journal of Human Genetics 71(5): $1082-1111$

46 Passarino G, Semino O, Quintana-Murci L, Excoffier L, Hammer M and Santachiara-Benerecetti AS (1998). Different genetic components in the Ethiopian population, identified by mtDNA and Y-chromosome polymorphisms. American Journal of Human Genetics 62(2): $420-434$

47 Semino O, Santachiara-Benerecetti AS, Falaschi F, CavalliSforza LL and Underhill PA (2002). Ethiopians and Khoisan share the deepest clades of the human Y-chromosome phylogeny. American Journal of Human Genetics 70(1): 265-268.

48 Rando JC, Pinto F, Gonzalez AM, Hernandez M, Larruga JM, Cabrera VM et al. (1998). Mitochondrial DNA analysis of northwest African populations reveals genetic exchanges with European, near-eastern, and sub-Saharan populations. Annals of Human Genetics 62: 531-550.

49 Ellis N, Hammer M, Hurles ME, Jobling MA, Karafet T, King TE et al. (2002). A nomenclature system for the tree of human Y-chromosomal binary haplogroups. Genome Research 12: 339-348.

50 Jobling MA and Tyler-Smith C (2003). The human Y chromosome: an evolutionary marker comes of age. Nature Reviews. Genetics 4(8): 598-612.

51 Underhill PA, Shen P, Lin AA, Jin L, Passarino G, Yang WH et al. (2000). Y chromosome sequence variation and the history of human populations. Nature Genetics 26(3): $358-361$.

52 Moran CN, Scott RA, Adams SM, Warrington SJ, Jobling MA, Bosch E et al. (2004). Y chromosome haplogroups of elite Ethiopian endurance runners. Human Genetics (submitted for publication).

53 Skaletsky H, Kuroda-Kawaguchi T, Minx PJ, Cordum HS, Hillier L, Brown LG et al. (2003). The male-specific region of the human $\mathrm{Y}$ chromosome is a mosaic of discrete sequence classes. Nature 423(6942): 825-837.

54 Beall CM (2003). High-altitude adaptations. Lancet 362 (Suppl): S14-S15.

55 Moore LG, Shriver M, Bemis L, Hickler B, Wilson M, Brutsaert T et al. (2004). Maternal adaptation to high-altitude pregnancy: an experiment of nature - a review. Placenta 25(Suppl. A): S60-S71.

56 Montgomery HE, Marshall $\mathrm{R}$, Hemingway $\mathrm{H}$, Myerson $\mathrm{S}$, Clarkson P, Dollery C et al. (1998). Human gene for physical performance. Nature 393(6682): 221-222.

57 Baker J and Horton S (2003). East African running dominance revisited: a role for stereotype threat? British Journal of Sports Medicine 37(6): 553-555. 